\title{
Comparative evaluation of EDTA, pyridine and acetic acid for the assessment of available heavy metals from domestic and industrial sludges
}

\author{
*A. A. Olajire, M. O. Bello, M. Abdul-Hammed and O. M. Olabemiwo \\ Department of Pure and Applied Chemistry, Ladoke Akintola University of Technology, Ogbomoso, Nigeria \\ Received 25 March 2006; revised 25 July 2006; accepted 20 August 2006; available online 1 October 2006
}

\begin{abstract}
Various sludge samples from different domestic and industrial wastewater treatment plants were analyzed by Flame Atomic Absorption Spectrometry (FAAS) to evaluate their total and available contents of heavy metals ( $\mathrm{Pb}, \mathrm{Hg}, \mathrm{Cd}$ and $\mathrm{Zn}$ ). The EDTA, pyridine and acetic acid single extraction techniques were applied to these samples with the objective of studying the leaching behavior of the metals in different sludges and also to predict their possible mobility when these wastes are disposed on the environment and landfills. In EDTA, higher extraction efficiency was observed for major part of the elements studied in the industrial sludges except for Hg and Cd, which were also considerably released from domestic sludges. Acetic acid and pyridine gave a better extraction efficiency for $\mathrm{Zn}$ in industrial sludge than EDTA. Moreover, the results of total digestions were compared, for total metal contents, with those obtained using pseudototal digestion procedure and a good correlation $\left(r^{2}=0.95\right)$ was found between the two methods of digestion.
\end{abstract}

Key words: Heavy metals, domestic sludges, industrial sludges, total digestion, pseudototal digestion

\section{INTRODUCTION}

The increasing production of sludges derived from the treatment of industrial and domestic wastewaters causes a new environmental problem due to their final disposal. Sludge is recognized as a valuable resource that can be recycled as fertilizer and soil improvement material for land because it contains organic compounds, macronutrients, micronutrients and nonessential trace elements, organic micropollutants, microorganisms and eggs of parasitic organisms (Alloway and Jackson, 1991). The high content of organic matter and substantial $\mathrm{N}$ and $\mathrm{P}$ concentrations suggests its use preferentially as a fertilizer in agriculture or as a regenerator for soil. Although such application may be beneficial to soil, concern about possible environmental pollution hazards, for example, odor, water pollution, veterinary hazards and contamination by heavy metals has to be considered (Sterrit and Lester, 1980; Alloway and Jackson, 1991; Perez-Cid, et al., 1996; Baveye, et al., 1999). In order to assess the potential environmental impact of materials

\footnotetext{
*Corresponding author, Email: olajireaa@yahoo.com Tel.:+2348033824264 ; Fax: +2348033824264
}

contaminated with metals, the determination of the total metal contents do not provide sufficient information, since the chemical forms (or species) of the metal in the sample matrix determine its mobilization capacity, bioavailability and related ecotoxicity (Ure and Davidson, 1995; Gupta, et al., 1996). In relation to this, sequential extraction method (Tessier, et al., 1979; Quevauviller, et al, 1993; McGrath, 1996 and Olajire, et al., 2003) and different leaching tests especially batch single extractions (McGrath, 1996 and Ure, 1996) are the most common methods for estimating the metal mobility in soil and sediment samples. Various techniques have been introduced to remediate metalcontaminated soils. One of these techniques is to separate the metals from soil by using chelating agents to form soluble metal-chelate complexes. Chelating agents such as ethylenediaminetetraacetic acid (EDTA) is the most commonly used chelates because of its strong chelating ability for different heavy metals (Norvell, 1991; Peters and Shem, 1992; Kim and Ong, 1998; Kim and Ong, 2000). The EDTA and acetic acid single extractions have been originally developed for soil and sludge analysis and they have been widely 
Olajire, A. A., et al.

applied in this way (Ure, 1996; Tack and Verloo, 1996); however little or no works were found in the literature to have been carried out on comparative evaluation of EDTA, acetic acid and pyridine extraction of $\mathrm{Pb}, \mathrm{Hg}$, $\mathrm{Cd}$ and $\mathrm{Zn}$ from sludge samples. In our opinion, it could be useful and interesting to adopt this method to evaluate the potential mobility of heavy metals from sludge samples under complexing or acidification processes developed in the environment, particularly when the sludges are disposed on landfill. The aim of the present study was to investigate the leaching of heavy metals ( $\mathrm{Pb}, \mathrm{Hg}, \mathrm{Cd}$ and $\mathrm{Zn}$ ) from domestic and industrial sludges, in order to evaluate the mobilizable content of them. Knowing fully well that the leaching behavior of sludge may be dictated by the type of sludge sample from which the sludge is obtained, a second objective of this work was to find the similarities and/or differences in EDTA, pyridine and acetic acid leaching behavior of domestic and industrial sludges, which could be classified as highly organic matter containing and typically inorganic sludges, respectively.

\section{MATERIALS AND METHODS}

\section{Sampling}

The description of the sampling sites is shown in Table 1 . The industrial sludge samples proceeded from the wastewater treatment plants of industries located at Ogba Industrial Estate, which includes Chemiron Pharmaceutical industry (site 4); Wamco Dairy Industry (site 5), vegetable oil industries (site 6). Other industrial sludes were obtained from Apapa Industrial Estate and this includes Flour Mills (site 7); Flour Mill Fertilizer section (site 8) and from Ijora Industrial area, which only includes Nitol Textile Industry (site 9). The domestic sludge samples were collected at various locations of wastewaters that proceeded from residence (site 1), and those that proceeded from residence close to scrap metal dumping (site 2) and local oil factory (site 3) in Sabo area of Ogbomoso. The samples were grouped according to their district and the source as follows: DS1 (site 1), DS2 (site 2), DS3 (site 3), IS1 (sites 4, 5 and 6), IS2 (sites 7 and 8) and IS3 (site 9) with DS, representing domestic sludges and IS, representing industrial sludges. All the sludge samples were collected by multiple sampling (about $2 \mathrm{~kg}$ ) in polyethylene containers and dried in the laboratory at $105^{\circ} \mathrm{C}$ (Zufiaurre, et al., 1998) in an oven to a constant weight. The dried samples were ground in a mortar and then sieved using nylon fiber sieve. Then the portion of samples were thoroughly mixed and homogenized on a clean polyethylene sheet with occasional mixing by hand. Finally, the prepared samples were bottled in polyethylene containers, which were stored at laboratory temperature in desiccators prior to analysis.

Table 1: The sampling sites and their descriptions

\begin{tabular}{|c|c|c|c|c|c|}
\hline $\begin{array}{l}\text { Site } \\
\text { No. }\end{array}$ & City & District & State & Source of sludge & Environment \\
\hline 1 & Ogbomoso & Sabo & Oyo & Domestic & Residential area \\
\hline 2 & Ogbomoso & Sabo & Оуо & Domestic & $\begin{array}{l}\text { Residential, close to scrap metal } \\
\text { dumping site. }\end{array}$ \\
\hline 3 & Ogbomoso & Sabo & Oyo & Domestic & Residential, close to local oil factory \\
\hline 4 & Lagos & Ikeja & Lagos & Industrial & Chemiron Pharmaceutical Industry \\
\hline 5 & Lagos & Ikeja & Lagos & Industrial & Wamco Dairy Industry \\
\hline 6 & Lagos & Ikeja & Lagos & Industrial & Vegetable oil Industry \\
\hline 7 & Lagos & Аpapa & Lagos & Industrial & Flour Mills Nigeria Plc. \\
\hline 8 & Lagos & Iganmu & Lagos & Industrial & $\begin{array}{l}\text { Fertilizer section of Flour Mills } \\
\text { Nigeria Plc. }\end{array}$ \\
\hline 9 & Lagos & Ijora & Lagos & Industrial & Nitol Textile Industry \\
\hline
\end{tabular}




\section{Reagents}

All reagents employed were of high quality analytical reagent grade. The stock solutions of metals (1000 g/ $\mathrm{mL}$ ) were prepared by dissolving the appropriate salts of the metals in doubly distilled water. Concentrated nitric (65\%), hydrochloric (35\%) and hydrofluoric (48 $\%)$ acids were employed for the digestion of the samples. The $0.05 \mathrm{~mol} / \mathrm{L}$ EDTA solution was prepared as an ammonium salt solution by dissolving the appropriate amount of the salt in concentrated ammonia solution and the $\mathrm{pH}$ was adjusted to $7 \pm 0.05$ by addition of a few drops of either ammonia or hydrochloric acid. The $0.43 \mathrm{~mol} / \mathrm{L}$ acetic acid solution was prepared by adequate dilution of the glacial acetic acid and 0.50 $\mathrm{mol} / \mathrm{L}$ pyridine solution was prepared by dilution of concentrated pyridine solution. The three extractant solutions were stored in stopped polyethylene bottles.

\section{Single extraction procedure}

The EDTA, acetic acid and pyridine single extraction were applied to all the pretreated sludge samples. Two replicates of each sample (for each extractant) were obtained and all the extractions were done in $50 \mathrm{~mL}$ capacity glass tubes, with the same tubes used for centrifugation, in order to prevent possible loss of sample. The extractions with EDTA, acetic acid and pyridine were carried out as described by Perez-cid, et al, 2002. Approximately, 2.5, 1.0 and $1.5 \mathrm{~g}$ of pretreated sludge sample were placed into centrifuge tube and 25, 40 and $30 \mathrm{~mL}$ of $0.05 \mathrm{~mol} / \mathrm{L}$ EDTA solution, $0.43 \mathrm{~mol} / \mathrm{L}$ acetic acid and $0.50 \mathrm{~mol} / \mathrm{L}$ pyridine were respectively added the mixtures were shaken for $1 \mathrm{~h}$. at laboratory temperature by means of a magnetic shaker. In all cases, after shaking, the suspension was centrifuged for $12 \mathrm{~min}$. at $2500 \mathrm{rpm}$. The supernatants were quantitatively transferred to volumetric flasks of $50 \mathrm{~mL}$ capacity, decanted into polyethylene bottles and stored at $4{ }^{\circ} \mathrm{C}$ until analysis. Blank extractions were carried out in parallel for each set of analysis using the same procedure as described above.

\section{Total and pseudototal digestions}

The determination of the total metal content in the sludges was carried out by completely dissolving the matrix of the sample by means of wet digestion procedure. In this case, $1.0 \mathrm{~g}$ of the sludge sample was placed in a $250 \mathrm{~cm}^{3}$ round-bottomed quick fit pyrex flask and $50 \mathrm{~cm}^{3}$ mixture of $30 \mathrm{~mL}$ nitric acid (65\%), 6 $\mathrm{mL}$ hydrochloric acid (35\%) and $14 \mathrm{~mL}$ hydrofluoric acid (48\%) were added in order to decompose the siliceous material present in the sludge. The flask was then connected to a $50 \mathrm{~cm}$ tall vigreux column, which was then connected to a $25 \mathrm{~cm}$ tall Liebig's condenser unit. The entire assembly was mounted on an electric heating plate. The samples were digested until clear solutions were obtained (approximately $6 \mathrm{~h}$.). The solutions were cooled and filter through acid-washed Whatman No. 1 filter paper and then made up to a volume of $100 \mathrm{~cm}^{3}$ using doubly distilled water. The solutions were stored at $4{ }^{\circ} \mathrm{C}$ prior to analysis. The pseudototal digestions of the sludges were carried out as follows; $30 \mathrm{~mL}$ of nitric acid (65\%) and $6 \mathrm{~mL}$ of doubly distilled water were mixed with $0.1 \mathrm{~g}$ of the sludge samples and the entire procedure was followed as described for total digestion. A reagent blank was prepared for each of the digestion procedure, following the entire sequence of steps as described for sample preparation in each case.

\section{RESULTS}

The analytical results obtained in the studied domestic and industrial sludge samples after total and pseudototal digestions are summarized in Table 2. The values are given as measure of duplicate determinations. As can be seen and contrary to what is generally expected, not always are domestic sludges less polluted than industrial sludges. Thus, in the three categorized industrial sludges analyzed in this study, only sample IS1 has, for all the elements studied, total heavy metals contents considerably higher than those of the domestic sludges; the other two categorized industrial sludges (samples IS2 and IS3) display lower total heavy metal contents to the domestic sludges. The results of the pseudototal digestion of all samples are also given in Table 1 . As was expected, the values were in all cases, smaller than those obtained with the total digestion procedure. However, it is important to emphasize that the results of pseudototal digestion were comparable to the total digestions for most of the elements analyzed in this study. The most significant differences between the two methods of digestions correspond to $\mathrm{Hg}$ in all the domestic sludge and in samples IS1 and IS2; and to $\mathrm{Pb}$ in industrial sludge. The EDTA, acetic acid and pyridine single extractions were applied, in duplicate, for metal leaching in all the studied samples. All the measurements were carried out using the standard addition technique and these results, expressed as a 
means of duplicate determinations are given in Table 3 . From the results of Table 3, it was observed that more extraction efficiency was achieved in both types of sludges when EDTA was employed as chelating agent. So, greater amounts of $\mathrm{Pb}$ and $\mathrm{Hg}$ in industrial sludge samples were leached using EDTA extraction procedure; $\mathrm{Cd}$ and $\mathrm{Zn}$ were extracted in a similar way from both samples. In acetic acid extraction, $\mathrm{Pb}$ and Zn were significantly leached from industrial samples IS2 and IS3 whereas low extraction efficiency was observed for all the metals in domestic sludges and in industrial sample IS1. When pyridine was employed, the extraction efficiency was practically insignificant for most of the elements studied, except for $\mathrm{Zn}$ in IS1, with extraction efficiency of $52.8 \%$ and for $\mathrm{Hg}$ in IS1 and IS2, with extraction efficiencies of $44.7 \%$ and $64.7 \%$ respectively. The rest of the elements were little or nothing leached in these samples, since the percentages of extraction were always lower than $11 \%$ except for $\mathrm{Hg}$ in sample DS3 (value around $28.6 \%)$.

\section{DISCUSSION AND CONCLUSION}

The results of elemental analysis of domestic and industrial sludges using total and pseudototal digestion methods are given in Table 1. The levels of $\mathrm{Hg}$ and $\mathrm{Cd}$ in sample IS1 are clearly higher than that of domestic sludge samples. The high Hg and Cd contents found in sample IS1 can be attributed to the usage of these elements in various products such as batteries, lamps and thermometers and in other industrial processes by industries in this location (i.e Ikeja Industrial Estate). The results have also demonstrated that industrial wastewaters have undergone some treatments before being discharged to the environment and that has actually accounted for the lower total heavy metal content as compared to the untreated wastewaters generated domestically. It is important to stress that the total metal content found in all the analyzed domestic sludge as well as industrial sludge except Hg in ISI, does not potent a pollution problem in agricultural uses (Sterritt and Lester, 1980). The values obtained for all the elements, using pseudototal digestion method are smaller than those obtained with total digestion procedure.

Table 2: Analytical results obtained in domestic and industrial sludges after pseudototal and total digestions

\begin{tabular}{|c|c|c|c|c|c|c|c|c|c|c|}
\hline \multicolumn{5}{|c|}{ Total digestion ( $\mu \mathrm{g} / \mathrm{g})$} & \multicolumn{6}{|c|}{ Pseudototal digestion $(\mu \mathrm{g} / \mathrm{g})$} \\
\hline $\begin{array}{l}\text { Site } \\
\text { No. }\end{array}$ & $\mathrm{Pb}$ & $\mathrm{Hg}$ & $\mathrm{Cd}$ & $\mathrm{Zn}$ & THMs & $\mathrm{Pb}$ & $\mathrm{Hg}$ & $\mathrm{Cd}$ & Zn & THMs \\
\hline 1 & $\begin{array}{r}40.85 \\
\pm 2.04\end{array}$ & $\begin{array}{c}5.60 \\
\pm 0.34\end{array}$ & $\begin{array}{c}0.19 \\
\pm 0.01\end{array}$ & $\begin{array}{c}114 \\
\pm 5.50\end{array}$ & $\begin{array}{l}160.64 \\
\pm 8.20\end{array}$ & $\begin{array}{l}40.62 \\
\pm 1.80\end{array}$ & $\begin{array}{c}3.30 \\
\pm 0.20\end{array}$ & $\begin{array}{c}0.12 \\
\pm 0.01\end{array}$ & $\begin{array}{c}106 \\
\pm 5.30\end{array}$ & $\begin{array}{l}149.92 \\
\pm 9.25\end{array}$ \\
\hline 2 & $\begin{array}{r}86.59 \\
\pm 3.50\end{array}$ & $\begin{array}{c}1.10 \\
\pm 0.07\end{array}$ & $\begin{array}{c}0.07 \\
\pm 0.01\end{array}$ & $\begin{array}{c}35.4 \\
\pm 1.75\end{array}$ & $\begin{array}{l}123.16 \\
\pm 7.20\end{array}$ & $\begin{array}{l}53.95 \\
\pm 2.70\end{array}$ & $\begin{array}{c}1.00 \\
\pm 0.02\end{array}$ & $\begin{array}{c}0.07 \\
\pm 0.01\end{array}$ & $\begin{array}{c}32.61 \\
\pm 1.96\end{array}$ & $\begin{array}{r}87.63 \\
\pm 4.50\end{array}$ \\
\hline 3 & $\begin{array}{c}26.0 \\
\pm 1.25\end{array}$ & $\begin{array}{c}2.80 \\
\pm 0.13\end{array}$ & $\begin{array}{c}0.08 \\
\pm 0.00\end{array}$ & $\begin{array}{r}28.70 \\
\pm 1.30\end{array}$ & $\begin{array}{r}57.58 \\
\pm 2.60\end{array}$ & $\begin{array}{l}15.30 \\
\pm 0.62\end{array}$ & $\begin{array}{c}1.20 \\
\pm 0.05\end{array}$ & $\begin{array}{c}0.05 \\
\pm 0.01\end{array}$ & $\begin{array}{r}14.70 \\
\pm 0.75\end{array}$ & $\begin{array}{r}31.25 \\
\pm 1.90\end{array}$ \\
\hline 4 & $\begin{array}{c}10.4 \\
\pm 0.50\end{array}$ & $\begin{array}{r}14.10 \\
\pm 0.85\end{array}$ & $\begin{array}{c}0.13 \\
\pm 0.01\end{array}$ & $\begin{array}{r}29.66 \\
\pm 1.20\end{array}$ & $\begin{array}{r}54.29 \\
\pm 2.80\end{array}$ & $\begin{array}{l}7.83 \\
\pm 0.40\end{array}$ & $\begin{array}{c}8.40 \\
\pm 0.45\end{array}$ & $\begin{array}{c}0.12 \\
\pm 0.02\end{array}$ & $\begin{array}{c}27.21 \\
\pm 1.65\end{array}$ & $\begin{array}{r}43.56 \\
\pm 2.65\end{array}$ \\
\hline 5 & $\begin{array}{c}5.07 \\
\pm 0.25\end{array}$ & $\begin{array}{c}9.60 \\
\pm 0.50\end{array}$ & $\begin{array}{c}0.10 \\
\pm 0.01\end{array}$ & $\begin{array}{r}31.79 \\
\pm 1.60\end{array}$ & $\begin{array}{r}46.56 \\
\pm 2.10\end{array}$ & $\begin{array}{l}3.74 \\
\pm 0.20\end{array}$ & $\begin{array}{c}5.80 \\
\pm 0.30\end{array}$ & $\begin{array}{c}0.09 \\
\pm 0.00\end{array}$ & $\begin{array}{c}30.24 \\
\pm 1.50\end{array}$ & $\begin{array}{l}39.87 \\
\pm 2.40\end{array}$ \\
\hline 6 & $\begin{array}{r}34.50 \\
\pm 2.10\end{array}$ & $\begin{array}{c}0.90 \\
\pm 0.04\end{array}$ & $\begin{array}{c}0.08 \\
\pm 0.01\end{array}$ & $\begin{array}{r}31.89 \\
\pm 1.30\end{array}$ & $\begin{array}{c}67.37 \\
\pm 3.50\end{array}$ & $\begin{array}{l}17.80 \\
\pm 0.90\end{array}$ & N.D & $\begin{array}{c}0.06 \\
\pm 0.01\end{array}$ & $\begin{array}{c}22.71 \\
\pm 1.40\end{array}$ & $\begin{array}{l}40.57 \\
\pm 2.50\end{array}$ \\
\hline 7 & $\begin{array}{c}0.75 \\
\pm 0.04\end{array}$ & $\begin{array}{c}1.70 \\
\pm 0.08\end{array}$ & $\begin{array}{c}0.04 \\
\pm 0.00\end{array}$ & $\begin{array}{c}5.46 \\
\pm 0.40\end{array}$ & $\begin{array}{c}7.95 \\
\pm 0.50\end{array}$ & $\begin{array}{l}0.43 \\
\pm 0.02\end{array}$ & $\begin{array}{c}1.70 \\
\pm 0.10\end{array}$ & $\begin{array}{c}0.04 \\
\pm 0.00\end{array}$ & $\begin{array}{c}5.42 \\
\pm 0.35\end{array}$ & $\begin{array}{r}7.59 \\
\pm .50\end{array}$ \\
\hline 8 & N.D & N.D & $\begin{array}{c}0.01 \\
\pm 0.00\end{array}$ & N.D & $\begin{array}{c}0.01 \\
\pm 0.00\end{array}$ & N.D & N.D & $\begin{array}{c}0.01 \\
\pm 0.00\end{array}$ & N.D & $\begin{array}{c}0.01 \\
\pm 0.00\end{array}$ \\
\hline 9 & $\begin{array}{c}0.65 \\
\pm 0.03\end{array}$ & $\begin{array}{c}1.40 \\
\pm 0.06\end{array}$ & $\begin{array}{c}0.07 \\
\pm 0.00\end{array}$ & $\begin{array}{c}3.70 \\
\pm 0.20\end{array}$ & $\begin{array}{c}5.82 \\
\pm 0.30\end{array}$ & N.D & $\begin{array}{c}1.30 \\
\pm 0.08\end{array}$ & $\begin{array}{c}0.07 \\
\pm 0.00\end{array}$ & $\begin{array}{c}3.53 \\
\pm 0.25\end{array}$ & $\begin{array}{c}4.90 \\
\pm 0.30\end{array}$ \\
\hline
\end{tabular}

N.D, not detected; DS1 (site No. 1); DS2 (site No. 2); DS3 (site No. 3); IS1 (site No. 4, 5 and 6); IS2 (site No. 7 and 8) and IS3 (site No. 9); DS, domestic sludge; IS, industrial sludge 
Comparative evaluation of EDTA...

Table 3: Analytical results obtained in domestic and industrial sludges using EDTA, acetic acid and pyridine single extractions

\begin{tabular}{|c|c|c|c|c|c|c|c|c|c|c|c|c|}
\hline \multicolumn{5}{|c|}{ EDTA } & \multicolumn{4}{|c|}{ Acetid acid } & \multicolumn{4}{|c|}{ Pyridine } \\
\hline $\begin{array}{l}\text { Site } \\
\text { No. }\end{array}$ & $\mathrm{Pb}$ & $\mathrm{Hg}$ & $\mathrm{Cd}$ & $\mathrm{Zn}$ & $\mathrm{Pb}$ & $\mathrm{Hg}$ & $\mathrm{Cd}$ & $\mathrm{Zn}$ & $\mathrm{Pb}$ & $\mathrm{Hg}$ & $\mathrm{Cd}$ & $\mathrm{Zn}$ \\
\hline \multirow{2}{*}{1} & 3.12 & 1.40 & 0.03 & 9.10 & \multirow{2}{*}{ N.D } & \multirow{2}{*}{ N.D } & \multirow{2}{*}{ N.D } & \multirow{2}{*}{ N.D } & N.D & \multirow{2}{*}{ N.D } & \multirow{2}{*}{ N.D } & \multirow{2}{*}{5.88} \\
\hline & \pm 0.20 & \pm 0.08 & \pm 0.00 & \pm 0.60 & & & & & \pm 0.50 & & & \\
\hline \multirow{2}{*}{2} & 4.52 & 1.80 & 0.03 & 4.08 & 3.54 & 0.30 & \multirow{2}{*}{ N.D } & \multirow{2}{*}{ N.D } & N.D & \multirow{2}{*}{ N.D } & \multirow{2}{*}{ N.D } & \multirow{2}{*}{3.80} \\
\hline & \pm 0.25 & \pm 0.13 & \pm 0.00 & \pm 0.33 & \pm 0.30 & \pm 0.00 & & & \pm 0.30 & & & \\
\hline \multirow{2}{*}{3} & 1.77 & 1.00 & 0.03 & 3.12 & 0.01 & 0.10 & \multirow{2}{*}{ N.D } & 0.02 & N.D & \multirow{2}{*}{0.80} & N.D & \multirow{2}{*}{1.18} \\
\hline & \pm 0.11 & \pm 0.01 & \pm 0.00 & \pm 0.20 & \pm 0.00 & \pm 0.00 & & \pm 0.00 & \pm 0.04 & & \pm 0.10 & \\
\hline \multirow{2}{*}{4} & 1.66 & 6.00 & 0.02 & 3.24 & 0.52 & \multirow{2}{*}{ N.D } & 0.03 & 6.43 & N.D & \multirow{2}{*}{6.60} & N.D & \multirow{2}{*}{40.37} \\
\hline & \pm 0.09 & \pm 0.50 & \pm 0.00 & \pm 0.26 & \pm 0.04 & & \pm 0.00 & \pm 0.52 & \pm 0.40 & & \pm 3.50 & \\
\hline \multirow{2}{*}{5} & 1.09 & 4.80 & 0.02 & 2.43 & 0.34 & 0.50 & 0.01 & 4.08 & N.D & \multirow{2}{*}{ N.D } & & \multirow{2}{*}{3.74} \\
\hline & \pm 0.08 & \pm 0.40 & \pm 0.00 & \pm 0.22 & \pm 0.02 & \pm 0.03 & \pm 0.00 & \pm 0.40 & \pm 0.22 & & & \\
\hline \multirow{2}{*}{6} & 2.33 & 1.60 & 0.02 & 3.92 & 0.94 & \multirow{2}{*}{ N.D } & 0.01 & 6.36 & N.D & \multirow{2}{*}{4.40} & N.D & \multirow[t]{2}{*}{5.21} \\
\hline & \pm 0.15 & \pm 0.10 & \pm 0.00 & \pm 0.35 & \pm 0.06 & & \pm 0.00 & \pm 0.60 & \pm 0.35 & & \pm 0.30 & \\
\hline \multirow{2}{*}{7} & 0.43 & 0.30 & 0.02 & 1.12 & 0.26 & & & 2.32 & & & & \\
\hline & \pm 0.02 & \pm 0.02 & \pm 0.00 & \pm 0.10 & \pm 0.02 & & & \pm 0.20 & & & & \\
\hline 8 & ס & N.D & 0.02 & 0 & 0.06 & D & 0.02 & 1.60 & N.D & 10 & N & NL \\
\hline 0 & & \pm 0.00 & \pm 0.05 & & \pm 0.00 & & \pm 0.00 & \pm 0.12 & \pm 0.01 & & & \\
\hline 9 & 1.20 & 1.20 & 0.02 & 0.61 & 0.30 & 0.10 & 0.01 & 1.75 & $\mathrm{~N}$ & D & $\mathrm{N}$ & $\mathrm{N}$ \\
\hline J & \pm 0.08 & \pm 0.11 & \pm 0.00 & \pm 0.05 & \pm 0.03 & \pm 0.01 & \pm 0.00 & \pm 0.20 & מט. & N.D. & D. & W.D \\
\hline
\end{tabular}

In order to establish a more detailed comparison between the two digestion procedures, the percentages of relative extraction between pseudototal and total digestion are shown in Figs. 1 (d) and 2 (d) for domestic and industrial sludges, respectively. According to these figures, it was found, for most of the elements analyzed in all sludge samples that a good agreement does exist between the compared results. The percentage of relative extraction ranged from 5.12 to $100 \%$ in domestic sludge for $\mathrm{Pb}, \mathrm{Cd}$ and $\mathrm{Zn}$. The lowest extraction efficiency corresponds to $\mathrm{Hg}$ in the domestic sludge. In the industrial sludges however, the percentages of relative extraction were also elevated for $\mathrm{Zn}$ and $\mathrm{Cd}$, and the values ranged from 85.9 to $100 \%$. The statistical comparison of the pseudototal and total digestion methods, using the regression analysis on the total metal contents showed that a good correlation $\left(r^{2}=\right.$ 0.95) does exist between the two methods of digestion. By taking the above into consideration, it is possible to say, although with some exceptions, that the results of pseudototal digestions are in good agreement with the total metal digestion. It can therefore be concluded that the pseudototal digestion could be employed as a screening method to approximately estimate the total metal content in domestic and industrial sludges. In addition, it is more rapid, simple and cost-effective in terms of reagent consumption. The EDTA, acetic acid and pyridine single extractions were applied for metal leaching in all the studied samples; and the results of the leaching test are given in Table 3. In order to compare the extraction efficiency of the EDTA, acetic acid and pyridine extraction in both domestic and industrial sludges, the percentages of relative extraction of the single extractions with respect to the total metal contents were shown in Figs. 1 (a-c) and 2 (a-c) for domestic and industrial sludges respectively. As can be seen from the figures, domestic and industrial sludges show a different behavior with respect to the applied leaching tests. As previously indicated, a more extraction efficiency was obtained using EDTA in domestic and industrial sludges, however acetic acid and pyridine gave a better extraction efficiency for $\mathrm{Zn}$ in industrial sludge than EDTA. Similarly, pyridine and EDTA gave a better extraction for $\mathrm{Hg}$ in industrial sludge than acetic acid. 

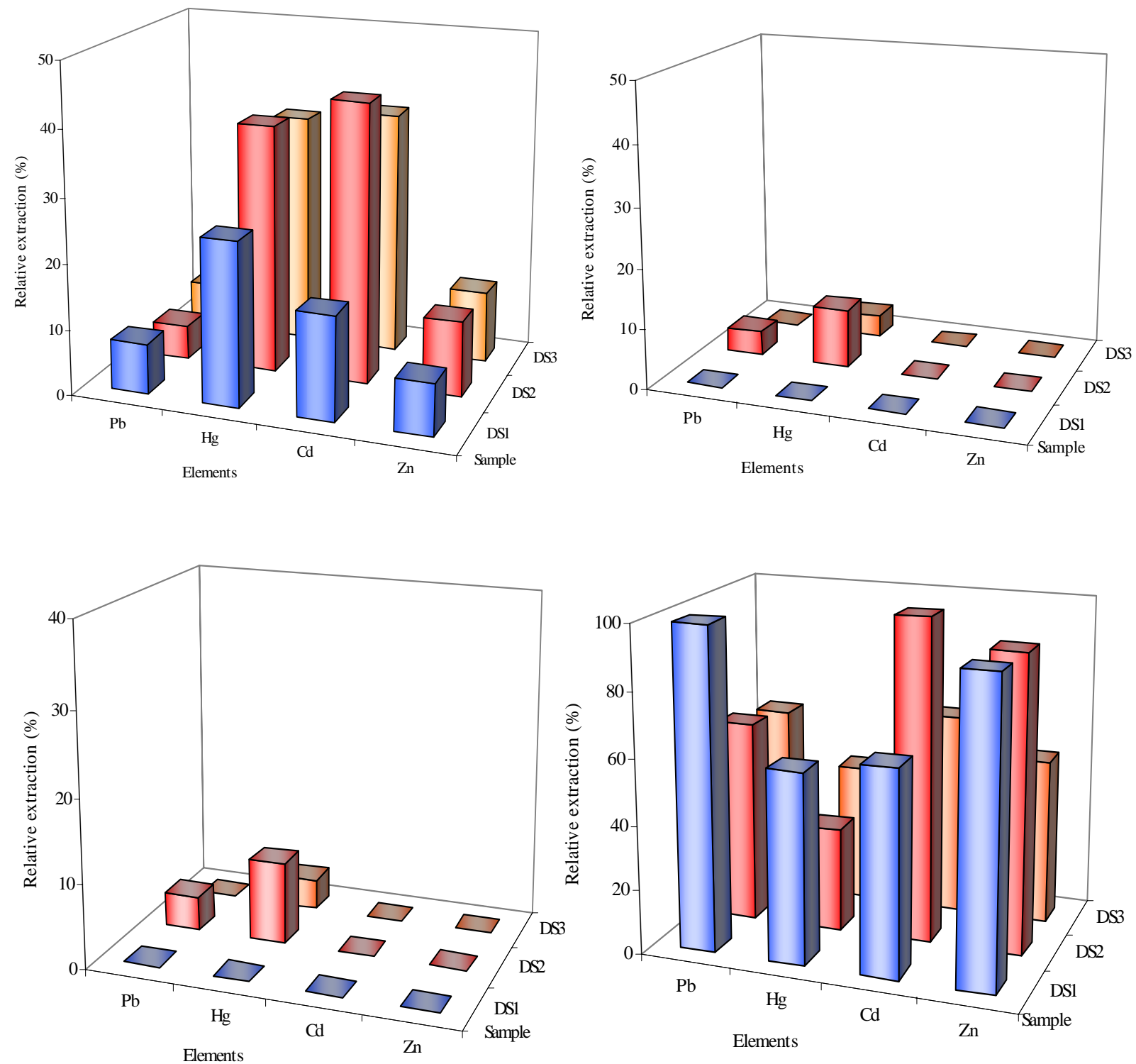

口DS1

๑ DS2

口 DS3

Fig. 1: Percentages of relative extraction corresponding to the EDTA (AD), acetic acid (BD), pyridine (CD), and pseudototal digestion (DD) with respect to the total metal contents in domestic sludges 

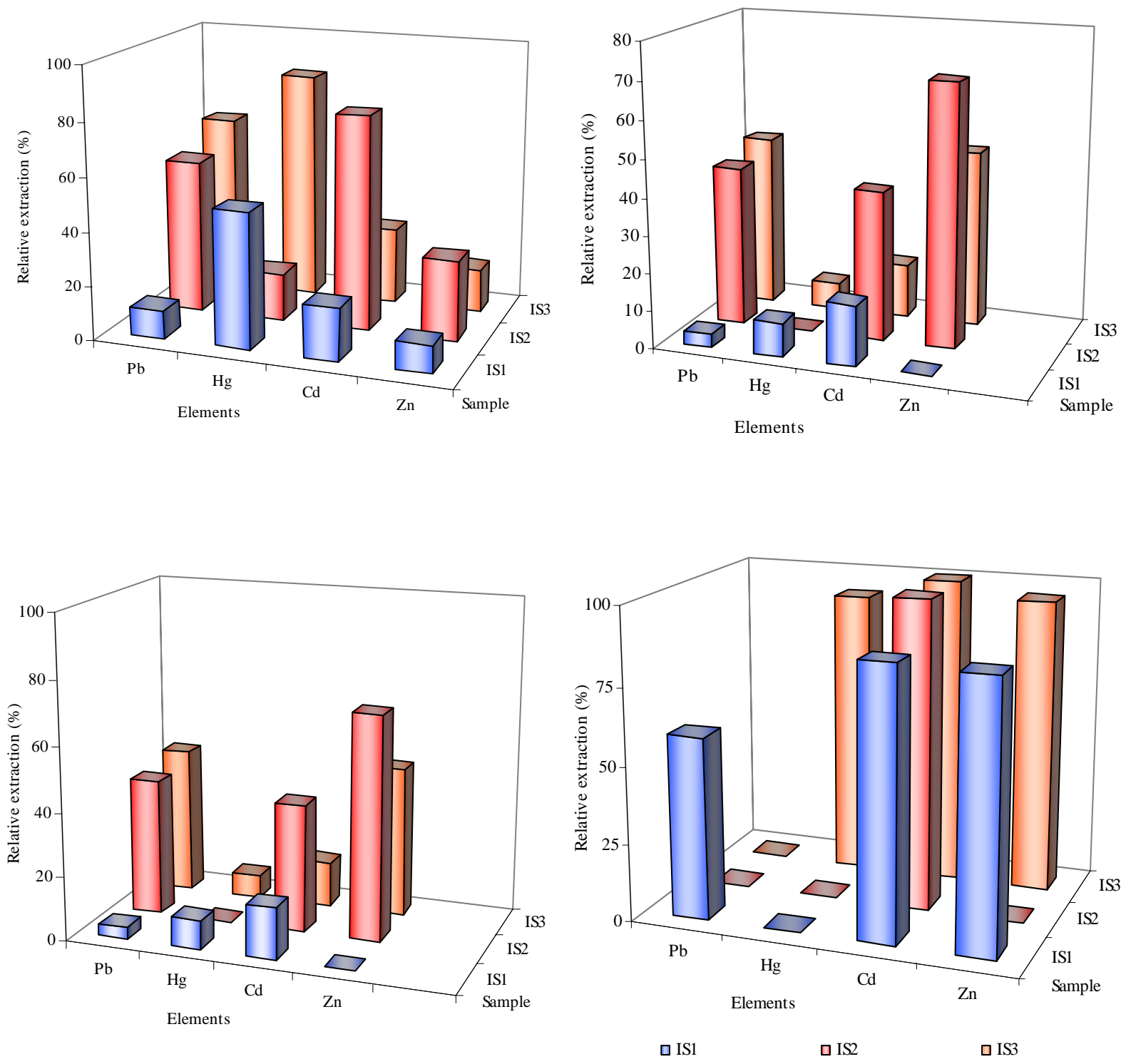

Fig. 2: Percentages of relative extraction corresponding to the EDTA (AI), acetic acid (BI), pyridine (CI) and pseudototal digestion (DI) with respect to the total metal contents in industrial sludges 
The variation in extraction efficiency of the EDTA, acetic acid and pyridine, essentially reflected the differences between sludges in their contents of the four heavy metals. Also, the thermodynamics of metalligand complexes, that is, the formation constants and more importantly, metal lability and/or the kinetics of metal desorption/dissolution exerted a large influence on the extraction efficiency of the four heavy metals. According to the results of this work, the application of EDTA, acetic acid and pyridine single extraction provide valuable information about the mobility, lability and availability of the four heavy metals from domestic and industrial sludges under different environmental conditions. The interest of this application is useful in the determination of leaching behavior of pollutants from different types of sludges, in order to assess their environmental impact and consequently select the best methods of disposal and possible re-use of such sludge for agricultural purposes without severe impact on plants. In the industrial sludge samples analyzed in this study, the mobility of the metals was more elevated in the presence of EDTA as complexing ligands and very little of $\mathrm{Pb}$ and $\mathrm{Zn}$ wee released in domestic sludges under these conditions. In acidic medium, $\mathrm{Pb}$ and $\mathrm{Zn}$ were significantly leached from industrial sludge sample IS2 and IS3 while Zn and Hg were significantly leached from industrial sludge when pyridine was employed as complexing ligands. On the other hand, the results of the pseudototal digestions, for most of the elements are comparable to the results of the total digestion in all samples studied except for $\mathrm{Hg}$ in all the domestic sludges and in samples IS1 and IS2; and Pb in industrial sludges. It thus implies that the pseudototal digestions could as well be employed as a screening method to approximately evaluate the total metal contents in sludge wastes.

\section{REFERENCES}

Alloway, B. J. and Jackson, A. P., (1991). The behavior of heavy metals in sewage sludge-amended soil. Sci. Total Environ., 100, 151-176.

Baveye, P., McBride, M. B., Bouldin, D., Hinesly, T. D., Dadhoh, M. S. A. and Abdel-Sabour, M. F., (1999). Mass balance and distribution of sludge-borne trace elements in a slit loam soil following long-term applications of sewage sludge. Sci. Total Environ., 227, 13-28.

Gupta, S. K., Vollmer, M. K. and Krebs, R., (1996). The importance of mobile, mobilisable and pseuo total heavy metal fractions in soil for three-level risk assessment and risk management. Sci. Total Environ., 178, 11-20.

Kim, C. S. and Ong, S. K., (1998). The elective reaction of lead and amorphous iron with EDTA in lead sulfate- contaminated soil system. Korean J. Environ. Eng. Res., 3 (3), 167-174.

Kim, C. S. and Ong, S. K., (2000). Effects of amorphous iron on extraction of lead-contaminated soil with EDTA. ASCE Hazardous, Toxic Radio. Was. Manag. Prac. Period., 4 (1), 16-23

McGrath, D., (1996). Application of single and sequential extraction procedures to polluted and unpolluted soils. Sci. Total Environ., 178, 37-44.

Norvell, W. A., (1984). Comparison of chelating agents as extractants for metals in diverse soil materials. Soil Sci. Soc. Am. J., 48 (6), 1285-1292.

Olajire, A. A., Ayodele, E. T., Oyediran, G. O. and Oluyemi, E. A., (2003). Levels and speciation of heavy metals in soils of industrial Southern Nigeria, Environ. Monit. Assess., 85, 135-155.

Perez-Cid, B., Lavilla, I. and Benedicho, C., (1996). Analytical assessment of two sequential extraction schemes for metal partitioning in sewage sludges. Analyst., 121, 1479-1484.

Perez-Cid, B., Silva, C. and Boia, C., (2002). Application of leaching tests for the assessment of available heavy metals from domestic and industrial sludges. Int. J. Environ. Anal. Chem., 82 (10), 721-732.

Peters, R. W. and Shem, L., (1992). Use of chelating agents for remediation of heavy metal contaminated soil. In: American Chemical Society Symposium Series 509: Environmental Remediation Ch 6: Use of Chelating Agents for Remediation of Heavy metal contaminated soil, 70-84.

Quevauviller, P., Rauret, G., Lopez-Sanchez, J. F., Rubio, R., Ure, A. and Muntau, H., (1997). Certification of trace metal extractable contents in a sediment reference material (CRM 601) following a three-step sequential extraction procedure. Sci. Total Environ., 205, 223-234.

Sterritt, R. M. and Lester, J. N., (1980). The value of sewage sludge to agriculture and effects of the agricultural use of sludges contaminated with toxic elements: a review. Sci. Total Environ., 16, 55-90

Tack, F. M. and Verloo, M. G., (1996). Impact of single reagent extraction using NH4Oac-EDTA on solid phase distribution of metals in contaminated dredge sediment. Sci. Total Environ., 178, 29-36.

Tessier, A., Campbell, P. G. C. and Bisson, M., (1979). Sequential extraction procedure for the speciation of particulate trace metals. Anal. Chem., 51, 84, 4-851

Ure, A. M., (1996). Single extraction schemes for soil analysis and related applications. Sci. Total Environ., 178, 3-10.

Ure, A. M. and Davidson, C. M., (1995). Chemical speciation in the Environment. Blackie, Glasgow.

Zufiaurre, R., Olivar, A., Chamorro, P., Nerin, C. and Callizo, A., (1998). Speciation of metals in sewage sludge for agricultural uses. Analyst., 123, 255-259. 
Comparative evaluation of EDTA...

\section{AUTHOR(S) BIOSKETCHES}

Olajire, A. A., Professor of Industrial Environmental Chemistry, Department of Pure and Applied Chemistry, Ladoke Akintola University of Technology, Ogbomoso, Nigeria,

Email:olajireaa@yahoo.com

Bello, I. A., Lecturer in Physical Chemistry, Department of Pure and Applied Chemistry, Ladoke Akintola University of Technology, Ogbomoso, Nigeria, Email: belloia2006@yahoo.com

Abdul-Hammed, M., Assistant lectureer in Physical Chemistry, Department of Pure and Applied Chemistry, Ladoke Akintola University of Technology, Ogbomoso, Nigeria,

Email:misbaulhameed@yahoo.co.uk

Olabemiwo, O. M., Lecturer in Industrial Chemistry, Department of Pure and Applied Chemistry, Ladoke Akintola University of Technology, Ogbomoso, Nigeria, Email: olabemiwo@yahoo.com

\section{This article should be referenced as follows:}

Olajire, A. A., Bello, I. A., Abdul-Hammed, M. and Olabemiwo, O. M., (2006). Comparative evaluation of EDTA, pyridine and acetic acid for the assessment of available heavy metals from domestic and industrial sludges. Int. J. Environ. Sci. Tech., 3 (4), 341-349 